\title{
8. Labour Mobility in the Pacific: Creating seasonal work programs in Australia
}

\author{
Nic Maclellan and Peter Mares
}

\section{Introduction}

Australia has long benefited from the labour of working people from the Pacific Islands, from the Kanakas who helped build the Queensland sugar industry in the 19th century, to women today, sewing Country Road shirts for a dollar an hour in a Fiji garment factory.

Pacific workers today are international and mobile: i-Kiribati and Tuvaluan seafarers staff the global shipping trade; Samoan and Tongan labourers work in factories and building sites in Sydney and Auckland or pick fruit in Australia's Murray Valley (often as 'illegal' or undocumented workers); more than 1,000 Fijians work in Iraq and Kuwait as security guards, truck drivers and labourers, while Fijian soldiers and police officers serve in peacekeeping operations around the globe. Meanwhile, Indo-Fijian and Tongan computer technicians, nurses, accountants and teachers migrate to find a better life, in the face of political turmoil and limited career opportunities in their homeland.

This movement of people has had a massive impact on the Pacific. In the colonial era, plantations of sugar in Fiji and pineapples in Hawai'i were built largely on migrant and indentured labour on alienated indigenous land. 'Blackbirding' in Melanesia robbed many islands of their young men between 1860 and 1900 and helped build the sugar industry in Queensland. ${ }^{1}$

Today, there is extensive domestic migration to Pacific towns and cities from rural areas and outlying islands. This internal population movement is often the precursor to international migration, either to other Pacific Island nations or to industrialised countries. It can also be 'circular' migration, with people returning to their home areas after fulfilling their desire for earnings, education or career advancement. Large numbers of people in the Pacific Islands migrate in search of the three Es: education, employment and enjoyment. Often they end up instead with the three Ds - jobs that are dirty, difficult and dangerous - and governments are left to deal with the social consequences of the three Ms: mobile men with money.

A high percentage of Polynesian and Micronesian Islanders now live overseas, especially in Pacific Rim countries such as Australia, Aotearoa/New Zealand, Canada and the USA. Some freely associated states and territories have migration 
rights to their former colonial power. In smaller islands such as Niue, Cook Islands, Rotuma and Wallis and Futuna, the number of people living overseas is greater than the numbers who remain. More Cook Islanders live in New Zealand than in the Cook Islands, more American Samoans in the USA than in their home islands. The geographer Gerard Ward (1999) suggests that the Polynesian triangle needs to be extended to incorporate Los Angeles, Sydney and Auckland.

Migration has become an outlet for the population pressures evident in many island nations and remittances sent home play a vital part in the economy of countries such as Tonga, Samoa, Niue, Tuvalu, Kiribati, the Cook Islands, Wallis and Futuna and Fiji. In turn, there is concern in Fiji, Tonga and Micronesia about the importation of Asian labour as domestic workers, sex workers and garment industry labourers. ${ }^{2}$

These patterns of migration provide benefits such as the transfer of remittances, the repatriation of skills and education, the promotion of tourism and the seeding of funds for small business development (Brown and Walker 1995). However, migration also has social costs. The immigration policies of developed nations favour those with skills and high levels of education, and there is an extensive literature on the 'brain drain' from the Pacific as rugby players, teachers, nurses, accountants and other professionals and tradespeople move to jobs offshore that offer better pay or career advancement.

In this way, Pacific Island nations are robbed of the skilled workers who are most needed, while low or semi-skilled workers who most need jobs are left behind and remain unemployed, with limited job opportunities in the formal wage sector. Labour force and population data from the Secretariat of the Pacific Community show that the youth bulge in most island nations will mean that employment generation will become increasingly urgent in the Pacific in coming decades, and there is growing discussion about the potential to address it through greater international labour mobility. ${ }^{3}$

The pressing need to find jobs for Pacific Island workers coincides with the emergence of gaps in the labour force of developed nations. In countries such as Australia, lower birth rates, the ageing demographic profile, increased personal wealth, the provision of social welfare, sustained economic growth, low unemployment and higher levels of education have combined to reduce the supply of workers who are available (or willing) to undertake physically demanding labour for relatively low pay. This has opened up debate about the potential for temporary employment schemes for Pacific Islanders to work in overseas labour markets, particularly in seasonal pursuits in agriculture.

This issue of labour migration and seasonal work is on the agenda of Pacific island governments and donor agencies: 
- a 2003 inquiry by Australia's Senate Foreign Affairs, Defence and Trade References Committee (2003: 69-75) on Australia's relations with the Pacific recommended that the Australian Government support civil society and private sector organisations to develop a pilot program for seasonal workers to come to Australia from the Pacific.

- the Forum Secretariat hosted a Remittances Roundtable in March 2005, studying the link between remittances, migration and labour market flexibility in current regional trade negotiations (Pacific Islands Forum Secretariat 2005).

- the ADB has published an overview of the role of remittances in Pacific Island economies, in the context of research on poverty and hardship in island countries (Connell and Brown 2005).

- the World Bank is currently conducting research on labour mobility and market access, investigating ways of improving migration opportunities so that Pacific labour can move to where the jobs are found in the region. ${ }^{4}$

- the Australian Agency for International Development (AusAID) is developing 'Pacific 2020' scenarios that look at demography and development projections for the next 15 years. ${ }^{5}$

At the October 2005 meeting of the Pacific Islands Forum, held in PNG, the issue of labour mobility was a key topic as Forum members discussed increasing regional integration. Pacific Island community, academic and government leaders widely express the belief that increased labour market access, especially for unskilled workers, is a central component of regional economic integration under the Pacific Plan adopted at the 2005 Forum. PNG's Foreign Minister, Sir Rabbie Namaliu, has stated: 'We believe that permitting increased labour mobility should be part of Australia's and New Zealand's commitment to implementing the Pacific Plan. It is one way to demonstrate to our leaders that they are serious about assisting island countries to develop their capacity and their economies' (Australian Financial Review, October 26, 2005, p. 8).

At the Forum meeting, however, Australia's Prime Minister, John Howard, firmly expressed his opposition to proposals to create temporary work schemes in Australia. ${ }^{6}$ In a December 2005 statement issued to the regional media, Australia's Foreign Minister, Alexander Downer, reiterated government policy against temporary work schemes, stating that the 'answer to the Pacific's large and growing unemployment problems does not lie in a few hundred unskilled young people coming to Australia to pick fruit for a few months of the year'. 7

In spite of Prime Minister Howard's firm 'no' to seasonal work programs at the 2005 Forum leaders' meeting, the issue is still being debated in Australia and there is continuing lobbying by business leaders and farmers' organisations. ${ }^{8}$ The Australian Senate Employment, Workplace Relations and Education Committee began a further inquiry into Pacific Region Seasonal Labour Programs 
in December 2005, to examine whether a seasonal work program could meet labour shortages in rural Australia and advance the economic development of Pacific nations. 9

As part of a wider research project conducted with the Institute for Social Research of Swinburne University, ${ }^{10}$ this chapter will briefly discuss the role of remittances in Pacific economies and development, before outlining a proposal for a pilot program of seasonal work for Islanders in Australia's horticulture industry. It will discuss Canada's Seasonal Agricultural Workers' Program (CSAWP) as a model for seasonal work programs, but will look at a range of issues - concerning regulation, labour rights and social impacts - that would need to be addressed if seasonal work schemes were to operate without evoking memories of blackbirding.

\section{Remittances and Pacific development}

\section{Labour mobility and trade negotiations}

Pacific Island governments have made gaining greater access to the labour markets of Australia and New Zealand an explicit policy goal. They see it as a crucial element in long-term job creation and social development. As a result, the issue of labour mobility has emerged as a key element in regional trade negotiations. The starting point of these various negotiations focused on trade in goods, but trade in services and labour mobility have become increasingly central to the discussions. There are three main strands to the trade negotiations involving Pacific Island nations: PICTA,the Pacific Island Countries Trade Agreement, covers trade in goods for the 14 Forum island countries excluding Australia and New Zealand. PICTA was endorsed at the Forum Heads of Government meeting in Nauru in August 2001 and provides for the phased elimination of tariffs between island countries. The larger island economies should have abolished most tariffs by 2009 and the smaller ones by 2011 . The phasing in of the agreement over this period is to be accompanied by strategies to help governments adopt alternative taxes and economic reform measures to compensate for the revenue they will lose from tariff reductions. PACER, the Pacific Agreement on Closer Economic Relations, was also endorsed at the Forum meeting in Nauru in 2001. It sets out a broader umbrella agreement for all Forum members including Australia and New Zealand. ${ }^{11}$ An Economic Partnership Agreement (EPA) is being negotiated between the EU and Pacific members of the African, Caribbean and Pacific grouping (ACP), under the Cotonou Agreement. A deal should be finalised by December 2007.

These three strands of trade negotiations are interlinked. For example, PACER requires that Australia and New Zealand be treated at least on the same negotiating basis as the EU. Hence, any provisions agreed to by Pacific Island nations under the EPA will have a flow-on effect on trade agreements with their 
more immediate neighbours. This is important since Pacific Island negotiations towards an EPA with the EU include discussions on labour mobility. As such they open the door to similar negotiations under PACER, a forum seen as far more crucial to Pacific Island governments given the much greater significance of the Australian and New Zealand labour markets as a potential source of future employment for Pacific Islanders. 12

The issue of greater labour mobility is a sensitive topic for Forum member governments, as the pace and manner of structural readjustment and trade liberalisation are being debated widely in the Pacific. The Asian Development Bank (1999) acknowledges that the Forum Economic Ministers' Meeting Action Plan is based on 'market friendly policies widely accepted as economically sensible, albeit politically difficult to implement'. But many NGOs and church organisations are critical of the process, arguing that trade agreements are finalised without parliamentary debate or extensive community consultation; that there has not been enough research and analysis of the social and cultural impacts of economic and trade reform; that economic models proposed for developing nations in Africa, Asia and Latin America are not appropriate for small island developing states; and that there are severe imbalances in island countries' political and economic weight compared with Australia, New Zealand and Europe, making the rhetoric of 'level-playing-field' negotiations a joke. ${ }^{13}$

The 'temporary movement of natural persons' (known as 'Mode 4') forms part of negotiations under the General Agreement on Trade in Services (GATS), however, the focus of Mode 4 discussions is on skilled workers, even though the lower-skilled services workforce is not excluded. Currently, the movement of labour from the Pacific to Australia focuses mainly on skilled trades and professional staff - nurses, teachers, rugby players, accountants and tradespeople - who have the necessary points for immigration and residency requirements. As well as permanent migration, there is already an increasing trend towards temporary entry for employment of skilled migrants in Australia - but discussion about temporary entry for unskilled workers is only just beginning (Riley 2005).

The loss of skilled workers is causing significant problems for island nations, but another concern is the growing pool of unskilled and semi-skilled workers who cannot find employment in the formal sector of island economies, especially as 40 per cent of island populations are aged under 20 years. ${ }^{14}$ For example, the Fiji Government estimates that there are about 17,000 new job seekers each year in Fiji (school leavers and late entrants to the job market), but only about 9,700 job opportunities in the formal sector (Fiji 2002: 42).

It is here that politics trumps economics and we see a shift from the language of 'trade' to the language of 'migration' in regional negotiations. As Professor Jane Kelsey (2005) of Auckland University notes in her study of the EPA negotiations, 
'Richer countries fear an influx of workers from poor countries, so they treat this as a trade issue when it involves skilled workers from those countries that fuel the "brain drain", but it reverts to an immigration issue when it involves low-skilled workers.'

\section{The growing importance of remittances}

Traditionally, smaller Polynesian states such as Tonga, Samoa, Tuvalu, Wallis and Futuna, Niue and the Cook Islands have been reliant on remittances from migrants or seasonal workers to complement Official Development Assistance (ODA) and very limited access to Foreign Direct Investment (FDI). There is currently renewed investigation of the ways in which remittances contribute to social and economic development in the Pacific, as part of a global academic debate about the role of remittances in investment as well as consumption (World Bank 2006). But it's clear that more Pacific workers are seeking employment in Pacific Rim countries and that remittances continue to play a central role in island economies for many Forum member countries.

For example, a crucial source of revenue for Tuvalu and Kiribati are the remittances of seafarers who crew vessels for international shipping companies from North America and Europe. The number of i-Kiribati seafarers has risen from 788 (in 1989) to 1,366 (in 1999) and the number of Tuvaluan seafarers from 67 (in 1996) to 241 (in 1999). Maria Borovnik's (2006) study of seafarers' remittances in Kiribati estimates that 57 per cent of funds remitted to wives are spent on basic needs, 30 per cent saved for investment and 13 per cent spent on school fees. For the seafarers themselves, 36 per cent don't save, 20 per cent have bought a house and land while 44 per cent are saving for a house and land. Because of the i-Kiribati tradition of bubuti (a request by a family member that cannot be refused), cash and goods coming into the community spread through the extended family, rather than remaining with one individual.

For its overseas exchange transactions, Tonga has seen a steady increase of private receipts through remittances in the past four years, from 105 million pa'anga (2001) to P184 million (2004). By comparison, in 2003-04, trade in merchandise raised just P28.3 million and services P52.7 million (National Reserve Bank of Tonga 2004: 6).

Even one of the Pacific's largest countries, Fiji, is increasingly reliant on overseas remittances, which are playing a crucial role in Fiji's foreign exchange earnings. The country has historically relied on sugar and gold mining, and more recently tourism and garment manufacture, but in the past decade, the amount of remittances has increased to a level where they earn more foreign exchange than other sectors except tourism (see Table 1). 
Table 1: Increase in foreign exchange earnings for Fiji, 1994-2004

\begin{tabular}{|c|c|c|c|c|c|c|c|}
\hline Year & Tourism & Remittances & $\begin{array}{c}\text { Textile, } \\
\text { clothing and } \\
\text { footwear }\end{array}$ & $\begin{array}{c}\text { Sugar and } \\
\text { molasses }\end{array}$ & Gold & Fish & $\begin{array}{c}\text { Mineral } \\
\text { water }\end{array}$ \\
\hline $\mathbf{1 9 9 4}$ & 393 & 56 & 163 & 266 & 63 & 64 & - \\
\hline $\mathbf{2 0 0 4}$ & 682 & 306 & 291 & 188 & 88 & 85 & 53 \\
\hline
\end{tabular}

Source: Reserve Bank of Fiji - figures in \$F million.

Of more than \$F306 million of remittances earned in 2004, \$F200 million came from the salaries and allowances of Fiji citizens working overseas. Given that significant amounts of remittances are transmitted directly within the family, such as cash carried by hand, these Reserve Bank figures underestimate the real amount. Fiji's Reserve Bank Governor, Savenaca Narube, notes, 'We are only capturing remittances that flow through the financial system. There are other kinds that are carried in person and sent through the ordinary mail. There are also those remittances in kind. One estimate puts these unrecorded remittances at over $\$ 150$ million, lifting total remittances above retained tourist receipts.' 15 The inflow of remittances in recent years is doubly important, given the significant outflow of funds through emigrant transfers. Fiji faces significant problems as skilled workers move offshore seeking better career paths, training and job opportunities. Many left Fiji after the 1987 and 2000 coups, including teachers, nurses, doctors and other professional staff. Since the 1987 coups, an estimated \$A696.9 million has left Fiji in the form of emigrants' transfers, with more than 5,000 people migrating from Fiji every year (Azmat 2005).

But many lesser skilled workers are going overseas too. Fijian women travel as domestic workers, aged carers and nannies to the USA or other Pacific countries, while Fijian men are increasingly recruited in military-related roles. As the US and British armed forces fail to meet their recruitment targets, they have been expanding their recruitment overseas. There are currently more than 2,000 Fijian soldiers in the British Army, and the UK Government is expanding recruitment in its former colony (BBC News Online, 9 November, 2004). Large numbers of Fijian men are also being recruited by private companies to work as soldiers, security guards, truck drivers and labourers to work in or near the conflict zone of Iraq.

\section{Case study: Iraq}

In January 2005, Fiji's Minister for Labour, Kenneth Zinck, announced that 'the Government knows that more men are leaving for Kuwait and Iraq and it is a good thing because it is providing employment for the unemployed. This is one solution to the increasing unemployment rate in the country today' (Fiji Times, 19 January, 2005). By mid-2005, there were more than 1,000 Fijians working in Iraq and Kuwait. They were employed by local subsidiaries of US and British security corporations, such as Global Risk Strategies, Homeland Security Limited, 
ArmorGroup, Sabre International Fiji, Triple Canopy and Meridian Services Agency.

More people are signing up for work in the Middle East, despite growing public concern at the number of casualties in Iraq, and even though returning troops have complained about the failure to obtain the promised benefits and welfare payments to families. ${ }^{16}$ Eighty Fijians recruited by Meridian Services as drivers in Iraq claimed in July 2005 that they had not been paid for the past three months. The men said that PWC Logistics had not met the promised pay rates and conditions set out in contracts signed in Fiji, with 100 men either terminated or simply walking off the job. One driver said:

Out of the 350 officers that are left here, we have quite a few who have been terminated, some have just left the job because they are not being paid and only those that have been paid buy food for the whole group. Some of us who could not stand this kind of living have returned to Fiji but the rest are here because we need the money to support our families (Fiji Times, 7 July 2005).

Returning personnel called for Meridian's local coordinator, Timoci Lolohea, to be investigated by Fiji's Labour Ministry and police, but, by January 2006, the issue had not been referred to police by the Labour Ministry (Fiji TV National News, 30 December, 2005). Some 20,000 people in Fiji have paid a registration fee of at least $\$ F 150$ to Meridian, in order to be listed for work in Kuwait, even though there were only 2,000 jobs on offer. Fijian journalist Samisoni Pareti (2005) has reported that villages have used their development funds to pay for application fees and that Meridian's recruitment drives have touched on Methodist Church networks, using church funds to pay for application fees, with the money repaid if a job is found in Kuwait.

The experience of recruitment of former soldiers and unskilled workers in Iraq and Kuwait raises some pertinent issues for any proposed recruitment for temporary work in Australia. Obviously, the security hazards and pay rates are different, but the boom of recruiting for Iraq and Kuwait has raised many issues for the Government of Fiji: the unregulated role of private recruitment contractors, the social impact on family life, and the capacity of government to support workers with pay disputes or post-deployment health problems. The Iraq/Kuwait experience also raises another set of questions about the social impact of labour migration on the family and community life of those left at home.

\section{Social impacts}

The 'paradise' image of Pacific life promoted by the tourist industry belies the significant changes in social structures in the Pacific, with changing patterns of work, urbanisation and gender roles. A number of people interviewed for this 
research stressed that traditional economies of rural villages were under challenge, and that seasonal worker schemes could exacerbate some trends. ${ }^{17}$ Current deployments of Fijian men as UN peacekeepers, British soldiers or private security guards in Iraq have provided evidence of psychological stress on children and negative impacts on educational standards. Church leaders reported a number of cases of family break-up, infidelity and new relationships forming, as one spouse worked overseas for lengthy periods. There are a number of anecdotal reports of Pacific men who had married in Australia to obtain residency rights, even though they had a wife and family at home. Community leaders are worried about how increased amounts of migrant work will affect gender roles in rural villages. There are concerns about the loss of male role models, and the potential impact that departing young workers will have on the traditional gendered allocation of jobs. An ageing population in rural areas, as young people migrate to urban centres or overseas, might impact on agricultural production and add burdens on already stressed health services. And there are particular burdens on ageing women. Women who have not worked in the formal sector do not have superannuation such as the Fiji National Provident Fund, and are reliant on financial support from working children. There is often an added burden of unpaid childcare for older women, as their daughters enter the workforce.

Women's groups such as the Fiji Women's Rights Movement (FWRM) and the Catholic Women's League of Tonga have reaffirmed concerns over a range of impacts on overseas workers: on women, on family life and on children. FWRM has conducted research surveys on sexual harassment in the workplace, and these problems could be exacerbated if women were working overseas as seasonal agricultural workers, unless there was close regulation and support to stop workplace harassment and bullying (Fiji Women's Right Movement 1998, 2002).

A growing concern is a pattern of suicide among Pacific youth in Fiji, Samoa, the FSM, the Marshall Islands, Palau and Guam, with the Pacific having the highest youth suicide rates in the world (UNICEF Pacific 1998). For Indo-Fijians and in Samoa, suicide rates among young women exceed those for young men, which is unusual for almost all populations in the world (Booth 2000). This youth crisis is in part connected to the absence of parents and relatives: researchers such as the Micronesian Seminar's Father Francis Hezel $(1985,1989)$ have highlighted the effects of globalisation as one of the many elements contributing to youth suicide, as customary and family mechanisms for conflict resolution have been shattered by migration. While extended families often used tight authority systems, they also provided older relatives with whom young men and women could talk about their problems. With family members working overseas, traditional family reconciliation mechanisms are not working as effectively. 
Pacific regional organisations have undertaken studies of the actions of overseas workers that have negative as well as positive impacts on the social and economic circumstances of dependants and communities. One interesting case study was conducted by the Secretariat of the Pacific Community on Tuvaluan and i-Kiribati seafarers' remittance spending and the economic and social implications of seafaring for community development (Dennis 2003). Although the type of work, recruitment and skill levels for sailors and length of absence are different to seasonal agricultural work, the study provides important pointers on social issues that would be useful in designing pilot programs for temporary agricultural work in Australia.

- The seafarers' wages were the basis of economic support for many people within the home community, ranging from one to 30 people. The report estimates that 4,200 people in Tuvalu (population 10,000) and 10,200 people in Kiribati (population 85,000) were directly dependent on the seafarers' incomes.

- Loss of employment by seafarers due to illness or injury had 'catastrophic' effects on the economic circumstances of some families.

- Wives and partners of seafarers reported difficulties maintaining contact with overseas workers, causing stress and depression. This was exacerbated because depression is not considered a real health problem in many Pacific cultures.

- Some seafarers engaged in unsafe sexual activity while overseas, often under the influence of alcohol. There is an increased risk of HIV/AIDS and STDs for these workers, but also for wives/partners who find it difficult to refuse unprotected sex when their husbands return from overseas, and face violence if they refuse.

- An increase in violence against spouses was also related to alcohol abuse, with returning sailors engaging in drinking sessions with their mates. Women were reluctant to report domestic violence to police in this case because 70-80 per cent were dependent on their spouse/partner's income.

- The majority of wives/partners and children reported difficulties resuming relationships with returning seafarers.

- There are complex gender and childhood development issues when parents communicate largely with their spouse rather than their children while overseas. Children also reported anger or annoyance at their father on his return, for disrupting household routines, ignoring their personal development, or diverting their mother's attention to caring for her spouse rather than her children.

- There is some internal migration from outer islands to Tarawa, as seafarers' families move to the capital to avail themselves of more time with their spouse/parent between voyages. 


\section{Remittances and development}

There has been a long debate among Pacific academics over economies based on the MIRAB model and the role of remittances in national development (Bertram and Watters 1985, Bertram 1999).

Many research studies around the world argue that remittances from secondand third-generation migrants will decline over time, due to family reunification in the overseas country or greater integration of the migrant into the host community. This suggests that it is dangerous for governments to base economic strategy on a continuing stream of remittances, which will ebb and flow according to a range of factors (e.g., migration policies, economic recession in receiving countries, or the adoption over time of individualistic values that clash with communalist village traditions). However, the ADB's March 2005 overview of remittances in the Pacific questions the generalisation of the unsustainability of remittance flows (Connell and Brown 2005). Although there is a need for further research, there are already Pacific case studies that indicate continuing financial support to family members at home from long-term migrants (Brown 1998, Somati and Gibson 2001). There are a growing number of case studies on the impact of remittances in the Pacific Islands. Researchers such as Richard Brown, John Connell (Connell and Brown 2005) and Avelina Rokoduru (2004) are looking at issues such as savings, investment, consumption and social impacts on women and family life. This research contributes to a global debate about the role of remittances in investment (World Bank 2006).

The World Bank, the Forum Secretariat and Pacific universities are engaged in new research programs to update data on remittance flows, and key questions are:

- Do some people remit more than others? (E.g., nurses are generally excellent remitters and seasonal workers returning home after temporary employment are also likely to remit a large proportion of income.)

- Significant amounts of remittances are used for consumption support rather than investment and savings, but there is a changing trend with evidence of investment in human and physical capital (e.g., children in households with family members overseas sending remittances appear to have higher education levels than those without). Beyond this, an increase in consumption is not necessarily a negative - it can have positive benefits for family welfare, if it results in improved housing, better sanitation and better nutrition (e.g., the replacement of wood-burning stoves with gas stoves in kitchens can dramatically improve women's health).

- What levels of funds are remitted to households without a family member overseas? (Continuing research by Professor Richard Brown of the University of Queensland shows that households in Tonga and Fiji receive remittances even if they don't have a family member overseas and that overseas migrants 
remit to organisations and their own business/superannuation funds, as well as to family members.)

- Not all remittances are in cash and significant amounts go back through informal means rather than the formal banking system (with people carrying cash by hand, transmitting funds through Western Union, or purchasing and carrying goods and other in-kind contributions). Can finance services be developed to assist cheap and efficient transfers of funds?

- Some people are more likely than others to invest (older and returning migrants; people with small businesses in the home country; occupational groups who remit generously). Can policies be tailored to encourage them to invest in community/cooperative/small business schemes?

A central issue is whether Forum member countries can develop options for seasonal and temporary work, rather than permanent migration, to allow new opportunities for work and remittances.

Pacific Islands Forum Secretary-General, Greg Urwin, notes that one major stumbling block to negotiating increased labour market access is the issue of reciprocity - whether Pacific Island countries will have to open their labour market to Australian and New Zealand workers in return for access for unskilled workers in the larger economies. ${ }^{18}$ Australia's Parliamentary Secretary for Foreign Affairs, Bruce Billson (2005a), stressed that opening the Australian labour market would be a two-way process. The opposition Australian Labor Party (ALP) supports increased labour mobility as part of a broader regional Pacific community. But the ALP's 2005 policy paper Towards a Pacific Community also says that, in return, there must be increased economic and administrative reform in island countries (Sercombe 2005). For the Government, Billson (2005b) also stated that the issue of labour market access would be negotiated as part of a package of trade issues, rather than as a separate treaty. But presenting the issue of labour market access as a trade issue removes the development focus of the whole process, and downplays many of the adverse social impacts - an issue of concern to Pacific Island governments, which see labour market access as primarily a development issue and one that should not require reciprocal rights of access for Australia and New Zealand. 19 Iosefa Maiava, Deputy Secretary-General of the Pacific Islands Forum Secretariat, notes that if there is to be reciprocity, it should be as equitable as possible recognising the different scales and different needs of Forum member countries' ${ }^{20}$

Pacific economists see an increase of remittances as an important source of boosting foreign reserves and addressing the severe balance of payments gap between Australia, New Zealand and Pacific island neighbours - a gap that is likely to only worsen if tariff protections are dismantled under PACER and imports replace domestic production. ${ }^{21}$ As University of the South Pacific economist Professor Wadan Narsey points out, in a future era of 'free' trade, 
remittances from temporary or seasonal labour schemes could replace key agricultural industries such as sugar as a source of revenue:

PACER will almost certainly add to the already substantial pool of unemployed labour, so remittances from the export of unskilled labour to Australia and [New Zealand] may turn out to be an important counterbalancing flow which reduces the size of the deficit, even if it is unlikely to completely eliminate it, and relieve pressure on the high rates of unemployment in Fiji. It may be emphasised that what needs to be investigated is not free and permanent access for [Fijian] unskilled labour, but temporary worker schemes for specific periods of time, in specific industries where Australia and [New Zealand] face labour shortages (Narsey 2004).

\section{Modelling seasonal work schemes in Australia}

\section{Seasonal work and horticulture - Australia and the world}

At the October 2005 Pacific Islands Forum, Prime Minister John Howard (2005) stated, 'We always have a preference for permanent settlement for migration. ... I think you either invite someone to come to your country to stay as a permanent citizen or you don't.'

Australia does already allow temporary entry, but only for full-fee paying overseas students and skilled workers. The business sector has increasing access to short-term visas - known as 'Business (Long-Stay)' or '457' visas — to bring in workers to cover skill shortages. Originally this category was used exclusively to bring in professionals such as IT specialists and medical staff but in recent years the catchment has broadened to include more traditional tradespeople such as welders (Robinson 2004). The number of temporary visas issued to skilled workers has jumped dramatically during the life of the Howard Government: there were 40,124 business long-stay visas granted in the 2003-04 financial year, up from just 9,600 in 1996-97 (Department of Immigration, Migrants and Multicultural Affairs 2005: 67-9, Moran 2004). The growth of this component of the migration program reflects an international trend towards micro- or niche migration schemes designed to overcome labour shortages in particular industries at particular times.

In other countries such schemes also extend to low or semi-skilled workers, particularly in agriculture. There has been 'a generally steady upward trend in inflows of seasonal workers since the beginning of the 1990s' and each year half a million seasonal workers from non-EU countries are employed in EU agriculture, especially in Germany, which issued 260,000 seasonal work permits in 2001 (United Nations Department of Economic and Social Affairs 2004, Ratha 2004). In fact, Australia and New Zealand might be the only developed nations that do not import seasonal labour for agriculture (Pickering and Barnes 2005). 
Currently primary producers in Australia's agriculture and horticulture sectors rely on documented ('legal') and undocumented ('illegal') workers to meet seasonal labour market needs. The documented workforce includes itinerant farm labourers, family members, local casual workers, students, grey nomads (retirees travelling around Australia) and backpackers on the Working Holiday Maker Scheme (Harding and Webster 2002). The undocumented workforce consists of unauthorised residents (primarily from Pacific Island, South-East Asian and Chinese backgrounds), overseas students working in excess of permitted hours, Australians working while in receipt of benefits and foreign travellers working without authorisation.

The rural sector is one of the four major areas of employment for undocumented workers in Australia. ${ }^{22}$ Union officials claim that 'a significant proportion' of Victoria's fresh fruit crop is picked by undocumented workers who are highly vulnerable to exploitation and in some cases are offered wages as low as \$A3 an hour (Hughes and Schwartz 2004). Meanwhile primary producers are vulnerable to immigration raids that can have a devastating effect on output during highly time-sensitive harvest periods.

The gross value of horticultural production in Australia in 2002 was estimated by the industry to be $\$ A 9.65$ billion, and by the Australian Bureau of Statistics to be $\$ A 6.75$ billion (Horticulture Australia Limited 2004). After rapid growth in the late 1990s, however, the fruit and vegetable industry currently faces significant challenges. Internationally, the high dollar has made Australian fruit and vegetables more expensive in markets where they must compete with subsidised European and North American produce and with produce from lower-wage countries such as China, South Africa and Chile. Domestically, the supermarket duopoly, increasing concentration in the food-processing sector, cheap imports of canned and frozen food and rising input costs (such as water, fuel and fertiliser) have growers in the grip of a cost-price squeeze. As a result of these pressures, traditional family farms are increasingly giving way to industrial-scale agriculture that can produce more efficiently through economies of scale (the number of farms in Australia declined by 25 per cent in 20 years to 2002-03 and average farm size increased from 2,720 hectares to 3,340 hectares) (Productivity Commission 2005: 31). The romantic image of Australian family farmers struggling to scratch a living from their own block of land is increasingly giving way to a more prosaic reality of professional farm managers and low-paid farm workers whose only connection to the land is that it supplies them with a job (Productivity Commission 2005: 99). ${ }^{23}$ Agricultural workers are the lowest paid workers in the economy and their jobs are more likely to be casual or part-time than in most other sectors (Productivity Commission 2005: 106-7). Combined with the process of rural flight, this has led to growing labour shortages that are often temporary and seasonal in nature. 
In response to pressure from the farm lobby, Immigration Minister, Amanda Vanstone, has created additional incentives for young travellers to take up agricultural work by allowing 'working holiday-makers' who do three months of 'seasonal harvest work in regional Australia' to apply for an additional 12-month visa. But the changes do not guarantee that backpackers will undertake a second stint of agricultural work and primary producers complain that backpackers' travel plans often take priority over working.

\section{Canada's Seasonal Agricultural Workers' Program}

Of the existing seasonal agricultural workers' schemes overseas, the one operating in Canada appears to provide the most useful lessons for Australia and the Pacific - not because it offers a perfect model that could be translated to Australian conditions, rather because it has been subject to extensive study and critique.

Canada's Seasonal Agricultural Workers' Program (CSAWP) has operated to bring temporary workers from the Caribbean since 1966 and from Mexico since 1974. In 2002, the program brought 19,000 workers to Canada (85 per cent of them to the province of Ontario) for an average of four months' employment. (The maximum stay allowable under the scheme is eight months.) Farmers need approval from local employment centres to certify that no Canadian workers are available to fill the jobs (though after the first year of involvement in the scheme such approval is largely perfunctory).

Farmers must provide the migrant workers with free housing (including meals or cooking facilities) and must guarantee them a minimum of 240 hours' work over six weeks at or above prevailing minimum-wage rates. Employers must take out workers' compensation insurance to cover the migrants in the case of industrial accidents, and must pay the cost of the migrants' international airfare, which can be partially recouped (to about 50 per cent). While working in Canada, the migrants pay local taxes and are covered by Canada's universal health care system.

A major study of CSAWP as a 'model of best practice and migrant worker participation in the benefits of economic globalisation' was undertaken by the North South Institute in Canada (Preibisch 2004, Griffith 2004, Downes and Odle-Worrell 2004). This research suggests that CSAWP has benefits at a number of levels.

For Canadian growers and Canadian rural communities:

- CSAWP increases labour reliability at times of peak demand, and enables growers to plan production increases with greater confidence.

- seasonal employment of foreign workers maintains and expands employment in higher skilled jobs, through the expansion of associated rural industries (e.g., transport services, construction, food processing). 
- local spending by seasonal migrant workers provides an economic boost to Canadian country towns and helps to sustain local businesses (e.g., shops) and services (e.g., banks, post offices) that might otherwise be in danger of closing.

- the scheme offers a legal route to farm jobs that would probably otherwise be filled by undocumented workers. Growers need not fear being in breach of the law or suffering the disruption of immigration raids.

For migrant workers:

- CSAWP provides opportunities for un- or underemployed Mexican and Caribbean workers to earn income at pay rates well above those on offer in their home countries.

- workers return home each year and use their savings and remittances to improve housing, nutrition, clothing and health care for their families. Workers and their families enjoy greater income security and increased access to consumer goods.

- the scheme has long-term development outcomes in source countries; in particular, the children of migrant labourers are likely to stay longer in school. (Jamaican workers were found to spend up to 35 per cent of remittances on children's education and there was a positive correlation between the number of years workers were employed in CSAWP and their children's school leaving age [Verduzco and Lozano 2004]) This finding is consistent with other surveys on the high proportion of migrant workers' remittances used to fund spending on children's education (United Nations Department of Economic and Social Affairs 2004).

- $\quad$ workers are spared the smugglers' fees and risky journeys required to enter North America without the appropriate papers, and can live free of the corrosive fear that they might be discovered working illegally. Unlike undocumented workers, they return home regularly and are not forced to endure long years of separation from loved ones.

- the scheme is more accessible to the very poor in the source countries, those who do not have the financial resources to pay the guides or bribes required to engage in cross-border travel as undocumented migrants. Greater equity is achievable, because recruitment of seasonal workers can be targeted at impoverished regions, the unemployed and the landless.

- the scheme creates mechanisms (at least on paper) to protect the rights of foreign workers in terms of wages, health and safety and regulated work hours - protections that are denied to undocumented workers.

The Canadian scheme is not, however, without its problems. The United Food and Commercial Workers' (UFCW) Union in Canada says the exploitation of migrant workers under CSAWP is a 'shameful little secret' (United Food and Commercial Workers' Union 2002: 21). There have been occasional protests and 
strikes by migrant workers, cases of abuse and exploitation, examples of substandard or overcrowded accommodation, and industrial accidents due to insufficient training, inadequate safety equipment or overlong working hours (Martin 2003, Basok 2003, Ferguson 2004). In Ontario, where most migrants are employed, agricultural workers are effectively prevented from organising in trade unions (although this is currently subject to legal challenge) and are not covered by workplace health and safety legislation (although provincial occupational health and safety laws will be extended to agriculture in June 2006).

One of the strengths of the Canadian scheme is that it operates under an umbrella of bilateral (government-to-government) agreements, which provide for an annual review. This means that problems and inadequacies in the scheme can be addressed, and contracts and regulations updated. The agreements also provide a formal mechanism (consular liaison officers) for workers to raise grievances through their diplomatic mission. There is, however, also a downside here: the consular liaison officers are seen to be too remote from the workers and to suffer from a conflict of interest (maintaining good relations with Canada and the smooth operation of the scheme versus taking up the fight on behalf of individual workers). Government officials in Canada and Mexico express frustration at the large amount of bureaucratic activity generated by a scheme that employs relatively small numbers of people.

Another positive feature of the Canadian scheme is that it provides continuity. Growers can request the same workers back each year, which means that they retain the skills that workers have built up and do not need to invest constantly in retraining. This can also be a plus for the migrant workers as they become familiar with their employer, their work, the local community and each other. Again, however, this strength of the scheme can also be a weakness. Workers are essentially 'bonded' to a particular employer for the duration of their stay in Canada, and the employer has an almost absolute power to send them home before their contracts expire, on the basis of 'non-compliance, refusal to work, or any other sufficient reason' (United Food and Commercial Workers' Union 2003: 14). Workers can thus be trapped in exploitative or abusive situations and have very little power to refuse unreasonable demands such as working excessive hours or in unsafe conditions.

\section{Labour mobility from the Pacific}

There is growing pressure for Australia to establish seasonal work schemes for the Pacific. Forum island governments are lobbying Canberra on the issue and the Melanesian Spearhead Group has argued for temporary access for workers with qualifications below tertiary level, including seasonal agricultural workers. 24 
In its 2003 inquiry on Australia's relations with the region, the Senate Foreign Affairs, Defence and Trade Committee received numerous submissions suggesting schemes to bring workers from the Pacific and recommended 'a pilot program to allow for labour to be sourced from the region for seasonal work in Australia.' (Senate Foreign Affairs 2003). In its formal reply to the Senate report, however, the Australian Government simply 'noted' the recommendation for a pilot study, adding a one-line response: 'Australia has traditionally not supported programs to bring low skilled seasonal workers to Australia.' 25 The obstacles to such a scheme are political and bureaucratic.

Firstly, there is a popular antipathy to 'cheap foreign labour' from Asia and the Pacific that has historical roots stretching back at least as far as the Victorian gold rush. Memories of 'blackbirding' also raise concern over the wages and working conditions for foreign workers.

Secondly, there is an entrenched orthodoxy within government that sees only highly skilled or capital-rich migrants as being of value to Australia. The bias against low-skilled migrants was formalised by the Fitzgerald Report into Australia's immigration program in 1988 and intensified further after 1996, as the Howard Government decisively shifted the emphasis of the migration program to favour skilled and business migrants at the expense of family reunion (Jupp 2003: 145-6).

Thirdly, despite the increase in temporary skilled migration, there remains a bias towards permanent, rather than short-term, migration. Australia's Department of Immigration, Multicultural and Indigenous Affairs (DIMIA) believes that temporary migrant labour schemes 'fail to provide long-term benefits for either sending or receiving countries'. ${ }^{26}$ Prime Minister John Howard responded to the idea of using overseas workers to pick fruit by saying on ABC Regional Radio that 'for a long period of time we have put our face against a guest worker approach', which could result in '[losing] control of a significant part of our immigration program' (Bedford 2004), while Treasurer Peter Costello has voiced the view that visas for short-stay 'guest workers' would be 'against the national ethos' (Colman 2005).

Fourthly, importing labour is problematic for the Australian labour movement. The national leadership of the Australian Council of Trade Unions (ACTU) has expressed some sympathy for the idea of a Pacific Island labour program with a developmental component and has even been involved in discussions about a proposed pilot program to bring workers from Fiji to Shepparton in central Victoria. But in the context of sweeping government changes that will weaken the role of unions in Australia's industrial relations system, the ACTU has firmed its opposition to 'circular' labour programs, arguing that international labour agreements should give Pacific workers the right to permanent residency. ${ }^{27}$ There has been vocal opposition from specific unions to the idea of bringing in 
'cheap' labour. Bill Shorten, President of the Australian Workers' Union (AWU), says, '[G]uest work arrangements are exploitative of the guest and exploitative of unemployed Australians.' (Metherell 2005). Australian unions have stressed that they would only support schemes that involved government and union regulation of wages and conditions and respected union membership.

A common argument for opposing temporary labour programs from the Pacific is that they would be discriminatory under Australia's immigration policy. There are, however, precedents for country-specific programs, such as the Working Holiday Maker Scheme in Australia, which provides travellers aged 18 to 30 with a 12-month visa that entitles them to work in Australia for up to three months at a time with any single employer. This scheme, based on bilateral agreements with 18 states or territories, does not take in any Pacific Island nations. ${ }^{28}$ Other countries have quotas restricted to Forum member countries, such as New Zealand's Pacific Access programs or the European agreement for a quota of i-Kiribati and Tuvaluan seafarers in the EU offshore shipping fleet.

Another frequent objection to the idea of seasonal labour programs in Australia is the fear that temporary workers will overstay their visas and 'disappear' into the community (adding to the stock of undocumented migrants). The Canadian experience suggests that this fear is greatly exaggerated. Of the 15,123 workers who entered Ontario under CSAWP in 2004, only 221 (or less than 1.5 per cent) were listed as going absent from their jobs without leave and some of these would have returned to their homeland early. All workers were reported to have left Canada and returned home by the end of the year (Foreign Agricultural Management Service 2004). Initially, the low overstay rate in the Canadian scheme was engineered through recruitment criteria that were skewed to select those seasonal workers deemed most likely to return to their homeland - that is, male workers who were married with children still at home (Basok 2000). Recently, however, the scheme has also been opened up to single men and to women.

The most important factor in the low overstay rates in the Canadian scheme appears to be that workers can return to their homeland with the expectation that they will be re-engaged to work in Canada under CSAWP the next year. This 'partly explains the lower number of overstayers compared with those in other similar programs' in other countries (United Nations Department of Economic and Social Affairs 2004). For example, a scheme in the UK to allow final-year university students from non-EU Eastern European countries to work in agriculture has an estimated overstay rate of 10 per cent (United Kingdom Home Office 2002). In the UK case, the seasonal migrants know that the opportunity to work in the UK is a one-off so the incentive to overstay is greater. 


\section{Requirements for effective seasonal workers' schemes}

Government officials and community leaders interviewed in the Pacific for this research all welcomed the idea of developing seasonal work schemes to allow Pacific Islanders greater access to the Australian labour market. However, church and NGO leaders all raised a range of issues about social impacts - on labour rights, family life and development outcomes for women - that would need to be addressed if such schemes were to function effectively. ${ }^{29}$ Global trends and the appealing symmetry of a scheme to allow foreign workers to fill seasonal gaps in Australia's rural labour market should not blind us to potential obstacles and dangers. The problems experienced with the Canadian scheme - despite its 'world's best practice' status - underline the need for careful design and implementation. The following sections outline some issues that need to be addressed in creating pilot seasonal work schemes.

\section{Labour rights and working conditions}

In Australia, trade union leaders stress that any seasonal work scheme must not be used to undercut wages and conditions for Australian workers, and must adhere to core labour conventions and standards. ${ }^{30}$ The International Labour Organisation (ILO) has a range of conventions covering core labour standards. The ILO also has specific conventions (97 and 143) covering migrant workers, yet these have not been ratified by Australia or by any Pacific Island governments. ${ }^{31}$ The Pacific Conference of Churches (PCC) has also called on Pacific governments to sign, ratify and implement the provisions of the Convention on Protection of the Rights of All Migrant Workers and Members of Their Families (Migrant Workers' Convention). ${ }^{32}$ The convention came into force in July 2003, but thus far has not been signed or ratified by Australia, New Zealand or any other member of the Pacific Islands Forum.

The experience in Canada suggests that problems will arise when migrant workers are tied to a specific employer, especially if there is no ability for them to organise collectively. Any seasonal labour scheme in Australia needs to have safeguards built in to protect workers' rights and guarantee freedom of association. There should also be a mechanism of independent dispute resolution to manage conflicts when they arise. Together with sectors such as construction and mining, farming and agricultural work are among the most hazardous industries for workers and compliance with occupational health and safety laws will be essential - there could be complex legal and practical issues for workers to claim treatment and compensation for workplace injuries after they return home. There is also a need to develop training programs for health and safety issues such as use of pesticides (which could have positive spin-offs for farm safety when the worker returns to farming and fishing in the Pacific). 


\section{Recruitment and government regulation}

The 2003 Senate Committee into Australia's relations with the region recommends a pilot scheme, but says that 'the model developed [should] provide for management and organisational arrangements to be the responsibility of the source country and adequate mechanisms be put in place for training and transfer of skills' (Senate Foreign Affairs 2003).

Such a proposal, however, places the burden on small island states, while the Australian Government and private sector reduce or avoid their responsibility for the costs as well as the benefits of seasonal work schemes. A more realistic approach would involve some government-to-government framework or treaty, as in Canada's CSAWP, outlining the responsibilities of both governments. Pacific governments will need extra resources to effectively manage the scheme, and in our view its operation should be integrated with the official aid program to ensure maximum development outcomes. There is a problem seeing these programs as simply an issue of 'trade in services', instead of a component of the social and economic development of Australia's nearest neighbours.

Unions believe that any seasonal workers' scheme must involve more than monitoring of conditions for temporary workers. The scheme must be regulated by government, and there must be a system of sanctions for breaches of those regulations. Australian and Pacific unions, through the ACTU and the South Pacific Council of Trade Unions, would seek collaboration with and involvement in any institutions created to regulate the scheme. ${ }^{33}$

The need for targeted and ethical recruitment of seasonal workers takes on particular importance given the disparities in wage levels between Australia and most island countries. There is anecdotal information on skilled workers travelling to Australia for fruit picking and unskilled labouring work, because they could earn more than their own trade or profession (e.g., schoolteachers who travel to Australia on a tourist visa during the long summer break, and go fruit picking for a couple of months after briefly visiting relatives). It is our view that recruitment schemes should be targeting the unskilled, rather than taking skilled trades and professional staff away from the workforce.

One pitfall for a more regulated scheme is that many rural villagers from the Pacific would have less comfort with a complex bureaucratic scheme, especially where the only High Commission is located in the capital city. Given low levels of literacy in Melanesian countries such as PNG, Vanuatu and Solomon Islands, and 'a cultural aversion to lots of paperwork' 34 from many Islanders, there might be costs and delays in regulation and recruitment procedures. Experience in Canada suggests that complexity can result in migrant workers missing out on their entitlements - for example, tax returns or worker's compensation because they do not have the skills to negotiate bureaucratic systems. Similarly, horticultural producers do not have time to deal with complex paperwork at 
the height of the harvest - so while a scheme must be regulated it also needs to be user friendly for workers and employers. There is also a need to develop 'a culture of saving', to encourage investment of remittances.

There is also a question of where employment contracts are signed, as this has some implications for labour rights: for example, under Fiji's Employment Act, signing a contract in Fiji allows provisions of the act to apply, while signing a contract overseas does not. This has implications if an employee wants the Ministry of Labour to follow up breaches of contract, unpaid or delayed wages, long-term occupational health problems, and so on.

Similarly, any seasonal labour program will need to take account of taxation agreements (or the lack of them) between Australia and the Pacific. Currently non-residents who perform harvest labour in Australia (working holiday-makers) are taxed at a higher rate than resident workers (29 per cent rather than 13 per cent) and do not benefit from the tax-free threshold (Australian National Audit Office 2005: 95-6). Unless this provision is altered, Pacific Islanders performing seasonal work could find themselves subject to double taxation.

There will be political issues relating to undocumented workers from Pacific Island countries, currently living or working in Australia and New Zealand in breach of their visa conditions. The creation of a regulated temporary work program could be accompanied by an amnesty, which would give time for undocumented workers to regularise their position, either as permanent migrants or as temporary workers. The issue of residency rights for workers is of crucial concern for Australian unions and Pacific communities in Australia, and migration policy would need to be coordinated with the introduction of seasonal work programs. 35

\section{Addressing social impacts on families}

Emele Duituturaga, Chief Executive Officer of Fiji's Ministry of Women, Social Welfare and Poverty Alleviation, states that the Government of Fiji 'would support a regulated, managed scheme for seasonal workers. We have few jobs and a limited industry and manufacturing base, with a young and growing population.' 36 Duituturaga stresses, however, that there are significant social impacts from migrant worker schemes - the benefits of increased income for the family and community must be weighed against the social costs, especially for women and children. There are also questions of how many benefits from remittances go directly to families, while the costs and burdens of welfare and social adjustment are carried by government, at a time when many Pacific governments are often stretched to capacity in providing basic services. In response to these social impacts, the Secretariat of the Pacific Community's Regional Maritime Program has developed social responsibility modules for training seafarers - it would be worth further study to see whether elements 
of these pre-departure training programs (e.g., on HIV/AIDS) could be adapted for use in pilot programs for seasonal agricultural workers. It is also worth considering whether a maximum length of absence should be imposed on the scheme to ensure that workers are not separated from their families for extended periods of time - for example, visas to work in Australia could be capped at six months within any 12-month period so that workers would be sure to spend at least half the year in their home communities.

\section{Information and community support}

There is a need for pre-departure training and information sessions for seasonal workers as a crucial element of any scheme. Informants stressed the importance of providing accurate and timely information to prospective seasonal workers before they joined schemes or travelled. Such information could cover a spectrum of issues, including wage rates, labour conditions (hours, meal breaks, occupational health and safety), cultural issues, visa and consular advice, banking and remittance procedures, etc. There could also be discussion of social issues that might face bored, isolated workers, including substance abuse, gambling and the risk of HIV/AIDS (Rokoduru 2004).

Local communities could discuss collectively issues of the increase of funds into the community, with advice on family budgeting or allocation of savings, planning family business ventures or investing in local community projects.

Our proposal suggests that pre-departure recruitment, training and orientation should involve a range of participants, representing governments of the sending and host nations, growers/employers, unions and church leaders. Such orientation programs could be funded by a levy on employers and applicants, or with government subsidy. Employers and governments could assist with communication between seasonal workers and their families/communities at home. Employers could provide telephones and computer terminals with Internet and email access in church or community centres in Australia, while sending governments, NGOs and aid donors could assist with computer-training programs for families at home. There is also the potential for Pacific Island communities and churches in Australia to play a support role for seasonal workers.

\section{Creating incentives to avoid overstaying}

As discussed above, a key concern with temporary labour programs is that workers will fail to return home when their seasonal work is ended. There is the potential for positive and negative incentives to reduce overstaying, which would involve governments developing policy that could assist seasonal workers to return to their home country.

Under its 'risk factor list' for assessing visa applications, the Australian Department of Immigration and Indigenous Affairs (DIMIA) already has strict 
requirements for visitors from Fiji, Tonga and other Pacific countries because of people overstaying in the past. DIMIA told the 2003 Senate inquiry into Australia's relations with the region that without 'very strong enforcement', the non-return of seasonal workers would incur significant expenses for government: 'Overstay issues associated with low-skilled guest worker schemes also cannot be underestimated, given the experience in other places. It is certainly true that overstay rates, non-return rates and the rates of protection visa applications from visitors from the South Pacific are quite high. They would be amongst the factors that we would need to take into account in considering any guest worker scheme.' (Senate Foreign Affairs 2003). However, Reverend Jason Kioa, President of the Tonga Australia Association, stresses that 'most overstayers are homesick - they really want to go back home, but are restricted by the potential legal and financial costs of being caught by Immigration'. 37

The dilemma for all undocumented workers is that they must stay below the radar for as long as possible in order to maximise their earnings in Australia: they know that once they are caught or decide to leave the country voluntarily, there will be no possibility of future return. Pacific church leaders in Australia are often involved in supporting parishioners in times of crisis (e.g., when a family member dies at home, but the overstayer cannot return home because of visa restrictions). Reverend Kioa believes that a scheme that would allow people to travel back and forth between Australia and Tonga would help reduce overstaying and the stresses on family life, and the breakdown of families by the extended absence of undocumented or migrant workers.

After the 2005 Pacific Islands Forum, Fiji's Prime Minister, Laisenia Qarase, stated: 'To me the most disappointing thing about this Forum is Australia's reluctance to start such a scheme. In my point of view, demand for seasonal or temporary labour always exists in those two countries and we know visitors to those countries have been employed illegally. Australia and New Zealand's concern [that] the scheme will increase illegal immigrants is not fair. This is a suggestion to put it on a proper arrangement, legally recognized with rules, regulations and a management system in place' (Fiji Times, 27 October 2005). Pacific Islands Forum Secretary-General, Greg Urwin, has also noted that seasonal migration to Australia by Pacific Islanders is different from past waves of postwar migration from southern Europe, in that many Islanders are landowners, maintain connections with extended family groups and have a continuing status in their home country. ${ }^{38}$ There is an extensive literature discussing this 'transnational network of kin' in the Pacific. ${ }^{39}$ Narsey has suggested: 'An essential part of the scheme could be the payment of a large proportion of the wages into trust funds for each worker, which are released in Fiji upon the satisfactory completion of the labour contract and return of the worker. This would not only ensure that Fiji enjoys the remittance benefits, but there is also an incentive for workers 
to abide by the rules and return after the end of the labour contract.' (Narsey 2004).

There is an important reservation to make in response to Dr Narsey's suggestion: if compulsory savings are to be deducted from the workers' wages, then it is imperative that at least some of this money is immediately available to family members in the home country for necessary living expenses. There are existing schemes where employers transmit funds home on a regular basis on behalf of the seasonal worker, such as the i-Kiribati and Tuvaluan seafarers' program (Dennis 2003).

There are other ways to maximise the likelihood of return. For example, it could be a requirement that workers return home before they can claim a refund for taxes paid in Australia, or before they can access superannuation contributions made by them or on their behalf. As in Canada, the recruitment criteria of seasonal workers could be skewed to select migrants deemed most likely to return to their homeland - that is, workers who are married with children still at home. There is a significant trade-off here, however, since such a selection bias requires the extended separation of a parent from his or her children. Selection criteria of this nature also discriminate against young, unmarried workers (such as school leavers), who might be those most urgently in need of a job.

It is our contention that the most powerful factor in ensuring that workers return home at the end of the season will be the secure knowledge that they can be re-engaged to work in Australia for a similar amount of time in subsequent years.

\section{Government policy to support migrant workers}

As well as developing disincentives, there is a need for Pacific governments to develop positive policies that encourage remittances and legal return. At present, few Pacific governments have comprehensive legislation or regulations to assist migrant workers with the rollover of any superannuation or pension rights; reduced freight costs to bring home goods; tax benefits for repatriated funds; and maintenance of seniority and leave entitlements for former government workers. Another problem is that costs of transferring remittances are relatively high, and sometimes insecure. Governments find it difficult to accurately account for the transfer of personal remittances, as people returning from overseas often carry cash or goods and hand it directly to family members, without any record in financial institutions.

Western Union is a major means of transferring funds from overseas, even though the rates are relatively expensive. The attraction of sending money through Western Union is the ease of access, especially in rural areas and outer islands where there are few commercial banks - an estimated 300,000 people in Fiji, out of a population of 870,000, do not have a bank account (ANZ 2004). With 
the increase in overseas remittances, commercial banks are looking to develop new products to tap the market of overseas migrants and seasonal workers in Australia, New Zealand and the USA.

The March 2005 Forum Secretariat Remittance Roundtable recognised a number of steps that governments could take to enable increased remittance flows (Pacific Islands Forum Secretariat, 2005):

- revising visa criteria to open up international labour markets to Pacific Island workers, particularly the unskilled;

- developing and promoting innovative and appropriate savings and investment instruments for overseas migrants and seasonal workers, encouraging workers to invest their pensions, bonuses and personal savings in the home country;

- developing more affordable and secure remittance systems (simplifying paperwork, and regulating and reducing costs for transferring money);

- adjusting tax policies for remitted funds, which are derived mainly from wages and salaries and have already been taxed overseas;

- developing government, NGO and church programs to look after the needs of migrant workers (information, social, consular assistance, human rights, etc.) and of family members left behind;

- improving financial literacy with advisory and training schemes to encourage returning seasonal workers to invest their earnings (e.g., business set-up advisory programs, micro-credit schemes, investment matching funds);

- adapting the educational, vocational and training curricula to reflect the fact that many workers are contributing to an international rather than domestic labour market.

\section{Sharing the costs}

As the above discussion makes clear, any seasonal labour scheme for Pacific Islanders to work in Australia will involve costs - the bureaucratic costs of regulation, administration and oversight, and the practical costs of airfares, visas, medical checks and accommodation. A key question in the design of the scheme will be how those costs are to be shared between growers, workers and governments without sacrificing equity or efficiency. As Philip Martin has noted, there has been a decline in the role of no-fee public sector employment services, and a rise in the role of for-profit private sector recruitment agencies. As a result, 'the general trend in the migrant recruiting business has been for costs to be shifted from employers to workers' (Martin 2005). In an unregulated environment, the disparity in wealth and opportunity between First- and Third-World countries creates conditions in which recruitment agencies can extract exorbitant 'application fees' from would-be migrant workers who are hungry for jobs, and then drive down the conditions and pay under which they 
are expected to work. As Martin comments, 'In most cases, migrants who have incurred debts to go abroad wind up being forced to make the adjustments from the promises to the realities, not employers' (Martin 2005: 3). This trend is objectionable for obvious reasons - it imposes the greatest costs on the most disadvantaged actors.

It is our view that employers should share the costs of any seasonal workers' scheme in Australia. Equity is only one consideration here; another is that there should be a monetary incentive for employers to look first to the local labour market to secure workers.

While Canada's scheme has been tailored much more heavily to the needs of employers than workers, it does provide a reasonable model of cost sharing. As noted above, growers must provide free accommodation in addition to wages. They also pay a non-recoverable fee of \$35 per worker to the Foreign Agricultural Resource Management Service (FARMS), an employer-run, non-profit, federally incorporated agency that is authorised by the Canadian Government to coordinate and organise the scheme. Workers' travel is organised through CanAg travel services, which is a subsidiary of FARMS. Farmers pay the cost of all transport within Canada, and must advance the cost of international travel with approximately half of this cost later recouped via deductions from workers' wages. Farmers must also pay the visa fee of \$CND150 up front, although this amount can be recouped fully through wage deductions. In recovering costs from workers, however, farmers can deduct a maximum of five per cent of gross earnings per pay period (in the case of Mexican workers) or $\$ 3.50$ a day (for Caribbean workers).

\section{Conclusion - beyond trade and economics}

If Australia is to introduce a seasonal employment scheme and open up its labour market to Pacific Island workers, the starting point should be a series of small-scale pilot projects. The scheme should not be conceived purely in terms of economic exchange, or as a bargaining chip in trade negotiations intended to further liberalise Pacific Island economies. Rather, it should be regarded as a development opportunity: a mechanism to advance, however modestly, sustainable economic and social development in the communities from which the workers come, and to encourage the expansion of 'people-to-people' contacts between Australia and the Pacific.

A model for this approach can be found in 'Agricultores Solidarios' (Farmers for Solidarity) in Spain. The Farmers' Union of Catalonia, the Livestock and Produce Farmers of Valencia and the Farmers' Union of Majorca have set up a program to meet their need for additional seasonal labour while also encouraging 'human, economic and social development in less favoured agrarian societies' (Peix nd). Under the program, seasonal migrant workers are recruited from Colombia, 
Morocco and Romania. There is a strong emphasis on training and on encouraging positive interaction between the migrant workers and their host communities in Spain. Program coordinator Maria Peix (2004) describes it as 'a two-way exchange that involves civil society', with the temporary workers becoming 'development agents that boost new processes led by themselves in their countries of origin'.

In Australia, we envisage building on the model of 'sister city' relationships that exists between some regional municipalities and localities in the Pacific. Under this scenario, a particular region (for example, Weather Coast in Solomon Islands) might be twinned with an area in country Victoria (such as the Swan Hill region). In addition to recruiting seasonal workers from a region of the Solomon Islands to work in horticulture, associated educational activities could be devised for schools in Swan Hill and community organisations (perhaps Pacific church groups) could take a lead role in organising social events and cultural activities to welcome the workers into the community. Volunteer programs (Australian Volunteers International and Australian Business Volunteers), service clubs (Rotary, Lions, etc.) and other NGOs could coordinate development activities with targeted communities. Workers would be engaged in some level of formal training - for example, in first aid, chemical safety and handling - to ensure that they go home with useful skills as well as money in their pockets. Community-based organisations in both countries could cooperate to develop ways for remittances to contribute to general development activities, through micro-finance schemes, small business programs and the education of young women.

Seasonal employment programs for Pacific Islanders to work in Australian horticulture are not a panacea for the challenges of unemployment and underemployment in Forum member countries. Nor will such schemes transform the economic development prospects of small island states or solve the challenges faced by Australian family farmers squeezed by rising prices, cheap overseas imports and an all-powerful supermarket duopoly. Nevertheless, a seasonal labour program does have the potential to make a material difference to the wellbeing of significant numbers of Pacific Island workers and their families especially those living in rural areas and outer islands. It also has the potential to significantly ease the seasonal labour shortages that hold back Australia's horticultural industry.

There are currently organisations seeking to initiate seasonal work programs, and regional bodies such as the Pacific Islands Forum should facilitate government-to-government discussions to create a framework for pilot projects - a contribution to the education, employment and enjoyment sought by many people in the Pacific. 


\section{References}

ANZ 2004. ANZ Coconut Wireless, Issue 3, November 2004.

Asian Development Bank, 1999. 'Pursuing Economic Reform in the Pacific', Pacific Studies Series No. 18, Manila: ADB.

Australian National Audit Office 2005. Audit Report No. 47 2004-05 Commonwealth of Australia, Canberra.

Azmat Gani 2005. 'Fiji emigrant transfers and potential macro-economic effects', Pacific Economic Bulletin 20(2): 117-28.

Basok, Tanya 2003. Tortillas and Tomatoes: Transmigrant Mexican Harvesters in Canada, Montreal and Kingston: McGill-Queens University Press.

Basok, Tanya 2000. 'He came, he saw, he ... stayed. Guest worker programs and the issue of non-return', International Migration, 38(2): 215-36.

Bedford, Kathy 2004. 'Interview with John Howard', Radio Broadcast $A B C$ Regional Victoria, 20 April, Retrieved 6 October 2006 from http://www.pm.gov.au/news/interviews/Interview805.html

Bertram, Geoffrey 1999. 'The MIRAB model 12 years on', The Contemporary Pacific 1: 105-38.

Bertram Geoffrey and Ray Watters 1985. 'The MIRAB economy in Pacific Microstates', Pacific Viewpoint 26(3): 497-519

Billson, Bruce 2005a. 'Australia to consider movement of labour around the Pacific', Radio broadcast, Pacific Beat, Radio Australia, 12 August.

Billson, Bruce 2005b. 'Forum countries consider regional trade framework', Radio broadcast, Pacific Beat, Radio Australia, 1 June.

Booth, Heather 2000. 'Suicide in the Pacific Islands', in Brij V. Lal and Kate Fortune (eds), The Pacific Islands: An Encyclopedia, Honolulu: University of Hawai'i Press, p. 439-440.

Borovnik, M. 2006. 'Working overseas: Seafarers' remittances and their distribution in Kiribati.' Asia Pacific Viewpoint 47(1), 151-161.

Brown, Richard 1998. 'Do migrants' remittances decline over time? Evidence from Tongans and Western Samoans in Australia' The Contemporary Pacific 10(1): 107-51

Brown, Richard and Adrian Walker, 1995. 'Migrants and their remittances', Pacific Studies Monograph No.17, Centre for Pacific Studies, Armidale: University of New South Wales.

Cole, Rodney (ed.), 1993. Pacific 2010: Challenging the future, Pacific Policy Paper 9, Canberra: National Centre for Development Studies. 
Colman, Elizabeth 2005. "'Guest" workers prop up economy', The Weekend Australian, 5-6 March, p. 1.

Connell, John and Richard Brown, 2005. Remittances in the Pacific - An overview, Manila: Asian Development Bank, March.

Dennis, Jennifer 2003. Pacific Island seafarers - a study of the economic and social implications of seafaring on dependants and communities, Suva: Pacific Seafarers Training Program, Regional Maritime Program, Secretariat of the Pacific Community.

Department of Immigration, Migrants and Multicultural Affairs 2005. Population Flows: Immigration Aspects 2003-04 Edition. Retrieved 6 October 2006 from http:/www.immi.gov.au/media/publications/statistics/ popflows2003-4/index.htm

Downes, Andrew and Cyrilene Odle-Worrell, 2004. Canadian migrant agricultural workers' program research project - the Caribbean component, executive summary, North South Institute, Retrieved 6 October 2006 from http://www.nsi-ins.ca/english/pdf/exec_sum_downes.pdf

Ferguson, Sue 2004. 'Hard Time in Canadian fields' Macleans, 11October. Retrieved 6 October 2006 from http://www.macleans.ca/topstories/canada/article.jsp? content=20041011_90409_90409

Fiji. 2002. Rebuilding confidence for stability and growth for a peaceful, prosperous Fiji, Strategic Development Plan 2003-2005, Parliamentary Paper No. 72, Fiji.

Fiji Women's Rights Movement, 2002. Sexual harassment in the workplace - the Fijian perspective, Suva: FWRM.

Fiji Women's Rights Movement, 1998. Labouring Under the Law, Suva: FWRM.

Foreign Agricultural Management Service 2004 Regional Report Caribbean/Mexican Seasonal Agricultural Workers Programs as of 31/12/2004. Canada.

Griffith, David 2004. The Canadian and United States migrant agricultural workers programs: Parallels and divergence between two North American seasonal migrant agricultural labour markets with respect to "best practices", executive summary. North South Institute. Retrieved 6 October 2006 from http://www.nsi-ins.ca/english/pdf/exec_sum_griffith.pdf

Harding, Glenys and Elizabeth Webster, 2002. The Working Holiday Maker Scheme and the Australian Labour Market, Melbourne Institute of Applied Economic and Social Research, University of Melbourne, Retrieved 6 October 2006 from http://www.immi.gov.au/media/publications/pdf/whm_ptl.pdf 
Hezel, F. X. 1989. 'Suicide and the Micronesian Family', The Contemporary Pacific $1(1): 43-74$

Hezel, F. X et al. (eds), 1985. Culture, Youth and Suicide in the Pacific: Papers from an East-West Center Conference, Working Papers Series, Pacific Islands Studies Program, Honolulu: University of Hawai'i.

Horticulture Australia Limited, 2004. The Australian Horticulture Statistics Handbook 2004

Howard, John2005. Australian Financial Review, October 26.

Hughes, Gary and Larry Schwartz 2004. 'Outlaw labour, rorts and all', Sunday Age, 28 March

Jupp, James 2003, From White Australia to Woomera: The story of Australian immigration, Cambridge: Cambridge University Press.

Kelsey, Jane 2005. A People's Guide to the Pacific's Economic Partnership Agreement, Suva: WCC, March.

Kelsey, Jane 2004. Big Brothers Behaving Badly — the implications for the Pacific Islands of the Pacific Agreement on Closer Economic Relations, Suva: PANG

Lee, Helen 2003. Tongans Overseas — between two shores Honolulu: University of Hawai'i Press.

Martin, Philip L. 2005. 'Merchants of labour: Agents of the evolving migration infrastructure', International Institute of Labour Studies' Decent Work Research Program, Discussion Paper DP/158/2005, International Institute for Labour Studies, Geneva

Martin, Phillip L. 2003. Managing Labour Migration: Temporary Worker Programs for the 21st Century, International Institute for Labour Studies, Geneva

Metherell, Mark 2005. 'Labour-starved nation flirts with overseas recruits', Sydney Morning Herald, 24 February,.

Ministry of Labour 2005. Occupational Health and Safety on Farms, Backgrounder05-83, Ministry of Labour and Ministry of Agriculture and Food, Canada, Ontario. Retrieved 6 October 2006 from http://www.labour.gov.on.ca/english/news/pdf/2005/05-83b.pdf

Moore, C. 1985. Kanaka — a history of Melanesian Mackay, Port Moresby: UPNG.

Moran, Susannah 2004. 'Temporary visas plug skills gap', Australian Financial Review, 24 September.

Narsey, Wadan, 2004. PIC development: Remittances and other alternatives to regional integration, paper presented at the FDC workshop on 
'Remittances, Microfinance and Technology: Leveraging development impact for Pacific States', Brisbane, June 10-11.

National Reserve Bank of Tonga 2004. Overseas Exchange Transactions' Annual Report 2003-04.Tonga.

Pacific Islands Forum Secretariat, 2005. Summary record — remittances roundtable 21 March 2005, Forum paper, March 29

Pareti, Samisoni 2005. 'Fiji's long, risky road to Kuwait', Pacific Islands Report, 22 April 2005. Retrieved 6 October 2006 from http://archives.pireport.org/archive/2005/April/04-22-ft.htm

Peix, Andreu no date. 'Farmers for Solidarity', Dossier Migrations et Développement. French Ministry of Foreign Affairs.

Peix, Maria 2004. 'Agricultores Solidarios' (Farmers for Solidarity) promote regular migration flows between temporary workers' countries of origin and of destination. Press release, Forum Barcelona, 4 September.

Pickering, Sue and Helen Barnes 2005. 'Towards a sustainable workforce across horticulture', The Orchardist (New Zealand), May, pp. 30-4

Preibisch, Kerry 2004. Social relations between agricultural workers, their employers, and the residents of rural Ontario, executive summary. North South Institute, Retrieved 6 October 2006 from http://www.nsi-ins.ca/english/pdf/exec_sum_preibisch.pdf

Productivity Commission 2005. Trends in Australian Agriculture, Commission Research Paper. Australian Government Productivity Commission, Canberra.

Ratha, Dilip 2004. 'Understanding the importance of remittances', Migration Information Source, Retrieved 6 October 2006 from http://www.migrationinformation.org/Feature/display.cfm?id $=256$

Riley, James 2005. 'Temporary visa jobs coming and going', The Weekend Australian, March 5-6.

Robinson, Paul 2004. 'Workers flown in from China', The Age, 21 December.

Rokoduru, Avelina 2005. 'Remittances, the case of Fiji's skilled migrant workers in the Republics of Kiribati and the Marshall Islands', presentation to Forum Secretariat Remittances Roundtable, 21 March.

Rokoduru, Avelina 2004. 'Fiji's women migrants and human rights - the case of nurses and teachers in the Republic of Marshall Islands', Journal of Pacific Studies 27(2): 205-227.

Russell, Roy 2004. Jamaican workers' participation in CSAWP and development consequences in the workers' rural home communities, executive summary, 
North South Institute, Retrieved 6 October 2006 from http://www.nsi-ins.ca/english/pdf/exec_sum_russell.pdf

Senate Foreign Affairs 2003. A Pacific Engaged - Australia's relations with Papua New Guinea and the islands of the south west Pacific, Canberra, Defence and Trade References Committee

Sercombe, Bob 2005. Towards a Pacific Community. Canberra, ALP Pacific Policy Discussion Paper.

Shanahan, Dennis, 2005. 'Howard, Clark shut out seasonal workers', The Australian, October 26

Simati, Aunese Makoi and John Gibson 2001. 'Do remittances decay? Evidence from Tuvaluan migrants in New Zealand', Pacific Economic Bulletin 16(1):55-63

United Nations Department of Economic and Social Affairs 2004. World Economic and Social Survey 2004, Part II, International Migration, New York: United Nations. http://www.un.org/esa/policy/wess/wess2004files/part2web/part2web.pdf

UNICEF Pacific 1998. State of Pacific Youth Report 1998, Suva: UNICEF Pacific.

United Food and Commercial Workers' Union 2003. National report: The status of migrant farm workers in Canada, December 2003. Canada: UFCW Canada and theCanadian Labour Congress. Retrieved 6 October 2006 from Retrieved 6 October 2006 from http://www.ufcw.ca/Theme/UFCW/files/ag2003e.pdf

United Food and Commercial Workers' Union 2002. National report: The status of migrant farm workers in Canada, December 2002. Canada: UFCW Canada and the Canadian Labour Congress. Retrieved 6 October 2006 from http://www.ufcw.ca/Theme/UFCW/files/National\%20ReportENG.pdf

United Kingdom Home Office, 2002. Review of the Seasonal Agricultural Workers' Scheme 2002 Work Permits UK, May, Retrieved 6 October 2006 from http://www.homeoffice.gov.uk/documents/cons-2002-saws

Verduzco, Gustavo and Maria Lozano, 2004. Mexican farm workers' participation in Canada's seasonal agricultural labour market and development consequences in their rural home communities, executive summary, North South Institute, Retrieved 6 October 2006 from http://www.nsi-ins.ca/english/pdf/exec_sum_verduzco.pdf

Ward, R. Gerard 1999. 'Widening Worlds, Shrinking Worlds? The Reshaping of Oceania', Pacific Distinguished Lecture, Centre for the Contemporary Pacific, ANU, Canberra. 


\title{
World Bank 2006. Global Economic Prospects 2006: The Economic Implications of Remittances and Migration, Washington: World Bank.
}

\author{
World Council of Churches Pacific Office, 2001. Islands of Hope - a Pacific \\ alternative to Economic Globalisation, Geneva :WCC
}

\section{ENDNOTES}

1 For discussion, see the special editions on 'Migration and labour' of the Journal of Pacific Studies, Vol. 18, 1994-95, and Vol. 27, 2, November 2004 and Moore (1985)

2 See, for example, the special edition of The Contemporary Pacific, 'Asia in the Pacific - migrant labour and tourism in the Republic of Palau', Vol. 12, No. 2, Fall 2000.

3 Labour force data from the Secretariat of the Pacific Community PRISM project at http://www.spc.int/prism/social/lab_force.html

4 The authors have contributed a chapter to the World Bank study At Home and Away: Expanding Job Opportunities for Pacific Islanders through Labour Mobility, 2006, on 'Improving Development Outcomes in the Pacific Through Labour Mobility'.

5 A decade ago, Australian academics and journalists contributed to the ideological push for economic policy change in the Pacific, through the Pacific 2010 Project, See Cole (1993).

${ }^{6}$ For examples of regional media coverage, see Shanahan (2005); 'Fiji prime minister miffed over Pacific work permits', Fiji Times, October 27, 2005; 'Aussie, Kiwi leaders cool to Pacific work permits', PNG Post-Courier, October 26, 2005; Cynthia Banham, 'Seasonal worker entry not on - $\mathrm{PM}^{\prime}$, Sydney Morning Herald, October 27, 2005.

7 Alexander Downer, 'Downer responds to allegations', Fiji Daily Post, December 2, 2005; 'Aussies against work schemes', Fiji Times, December 2, 2005. See also transcript of interview on Downer's web site, September 30, 2005: http://www.foreignminister.gov.au/transcripts/2005/050930_abc.html

8 See, for example, interviews with Bob Lyon (Vice-President of the Australia-PNG Business Council and immediate past President of the Australia-Pacific Islands Business Council), 'More calls for Australian labour mobility scheme', Pacific Beat, Radio Australia, 15 December, 2005; Duncan Fraser of the National Farmers' Federation, 'Farmers support call to allow Pacific seasonal workers', Pacific Beat, Radio Australia, 27 October, 2005; Professor Robbie Robertson, Director of Development Studies, University of the South Pacific, 'Academic rejects labour mobility concerns', Pacific Beat, Radio Australia, 7 December, 2005.

9 The inquiry is due to report in August 2006. See: 'http://www.aph.gov.au/Senate/committee/eet_ctte/contract_labour/index.htm'

10 Peter Mares and Nic Maclellan work as journalists and are research fellows at the Institute for Social Research at Swinburne University in Melbourne, Australia. This paper draws on their continuing research for the 'Pacific Labour and Australian Horticulture' project, funded through the Australian Research Council Industry Linkage scheme. Their industry partners are Oxfam Australia, Swan Hill Rural City Council and the Sunraysia Mallee Economic Development Board.

11 PACER came into force in October 2002 and PICTA came into force in April 2003 after six countries ratified it. The text of the two agreements can be found on the Pacific Islands Forum Secretariat web site at www.forumsec.org.fj

12 Interview with Forum Secretary-General, Greg Urwin, Suva, June 2005. See also Narsey (2004).

13 For church and NGO critiques, see World Council of Churches Pacific Office (2001), Kelsey (2004) and (2005).

14 Population data and demographic trends for island nations are detailed by the Secretariat of the Pacific Community Demography/Population Program: http://www.spc.int/demog/

15 Savenaca Narube, Governor of the Reserve Bank of Fiji, transcript of speech to the Fiji Australia Business Forum, 17 October, 2005: http://www.bis.org/review/r051019c.pdf

16 'Fijians survive bloody shoot-out', Fiji Sun, December 23, 2003; 'Iraq guards sent home in disgrace', Fiji Times, 26 December, 2003; 'Iraq guards come home to pay battle', Fiji Times, 20 January, 2004.

17 Interviews with Prof. Ron Duncan (PIAS-DG, USP), Seema Naidu (FWRM), Avelina Rokoduru (USP), Tupou Vere (PCRC), Suva, June 2005; Betty Blake (Catholic Women's League of Tonga), June 2005.

18 Interview with Forum Secretary-General, Greg Urwin, Suva, June 2005. 
19 Interview with Sanjesh Naidu, Ministry of Finance and Planning, Government of Fiji, Suva, June 2005.

20 Iosefa Maiava, Deputy Secretary-General of the Pacific Islands Forum Secretariat, World Bank seminar on remittances and labour mobility, Suva, November 2005.

21 Interview with Resina Katafono, Senior Economist, Reserve Bank of Fiji, Suva, June 2005.

22 The other main sectors being hospitality, the sex industry and factories.

23 Over the 20 years to 2003-04, the proportion of employees in the agricultural workforce has increased from 33 per cent to 51 per cent, while the combined share of employers' own account and contributing family workers has fallen from 67 per cent to 49 per cent.

24 Interviews with Greg Urwin (Forum Secretariat), Emele Duituturaga (Fiji), Sanjesh Naidu (Fiji), Akilisi Pohiva (Tonga), June 2005.

25 Government response to A Pacific Engaged, Canberra, April 2005. This formal response to the August 2003 Senate report was dated April 5, 2005, but was issued only on June 24, 2005, the day after Parliament broke for its winter recess.

26 Submission to 2003 Senate inquiry. See Senate Foreign Affairs (2003)

27 'Unions support Senate report on labour mobility', interview with ACTU President, Sharan Burrow, Pacific Beat, Radio Australia, August 13, 2003. Interviews with Alison Tate, International Officer, Australian Council of Trade Unions (ACTU), Melbourne, June 2005; Alan Matheson, former ACTU International Officer, Melbourne, May 2005.

28 Australia's current reciprocal working holiday arrangements are all with the developed states or territories that the Immigration Department regards as posing a 'low immigration risk', namely Belgium, Canada, Cyprus, Denmark, Finland, France, Germany, Hong Kong, Ireland, Italy, Japan, Korea, Malta, Netherlands, Norway, Sweden, Taiwan and the UK. NSW MLC Charlie Lynn has called for the working holiday scheme to be extended to PNG. 'It's time to dump our "unofficial" White Australia policy against black Melanesians', media release, February 23, 2005.

29 Interviews with Reverend Jason Kioa (Tongan Australia Association), Melbourne, May 2005; Father Kevin Barr (Ecumenical Centre for Research, Education and Advocacy [ECREA]), Suva, June 2005; Betty Blake, Catholic Women's League of Tonga, Nuku'alofa, June 2005; Revered Simote Vea, Tonga National Council of Churches, Nuku'alofa, June 2005; Reverend Leva Kila Pat, Pacific Conference of Churches, Suva, June 2005; Feiloakitau Kaho Tevi, World Council of Churches Pacific Office, Suva, June 2005.

30 Interview with Rajeshwar Singh, President, South Pacific Council of Trade Unions, Suva, June 2005; interview with Tate, Matheson, op. cit.

31 ILO C. 97 Migration for Employment Convention (Revised), 1949, and ILO C. 143 Migrant Workers (Supplementary Provisions) Convention, 1975.

32 Interviews with Tevi, Kila Pat and Vea, op. cit.

33 Interviews with Tate, Matheson, Singh, op. cit.

34 Interview with Reverend Jason Kioa, May 2005. The issue was also raised by Avelina Rokoduru, interview, Suva, June 2005.

35 Interview with executive of Tongan Australia Association, Melbourne, November 2005.

36 Interview with Emele Duituturaga, Suva, June 2005.

37 Interview with Reverend Jason Kioa, May 2005.

38 Interview with Forum Secretary-General, Greg Urwin, Suva, June 2005.

39 For the example of Tonga, see Lee (2003) 